\title{
Adherence and/or discontinuation of imatinib mesylate in patients with chronic myeloid leukemia
}

\author{
Alexandra Rodrigues Alves ${ }^{1}$, William Gustavo Lima ${ }^{1}$, Michelly Martins Nagai ${ }^{2}$, João Paulo Vilela \\ Rodrigues $^{2}$, Lorena Rocha Ayres ${ }^{3 *}$
}

\begin{abstract}
${ }^{I}$ Campus Centro Oeste Dona Lindu, Federal University of São João Del Rei, Divinópolis, Brazil, ${ }^{2}$ Research Center of Pharmaceutical Services and Clinical Pharmacy (CPAFF), School of Pharmaceutical Sciences of Ribeirão Preto, University of São Paulo, Ribeirão Preto, Brazil, ${ }^{3}$ Department of Pharmaceutical Sciences, Health Sciences Center, Federal University of Espírito Santo, Vitória, Brazil
\end{abstract}

\begin{abstract}
Adherence to imatinib mesylate improves clinical outcomes and promotes a reduction in health expenditure. However, treatment duration and lack of efficacy decrease adherence to pharmacotherapy, resulting in increased mortality associated with Chronic Myeloid Leukemia. This study aimed to evaluate and compare adherence and/or discontinuation of imatinib mesylate in different studies from the literature. An integrative review of original articles published between the years of 2004 and 2014 was performed using the databases PubMed/MEDLINE, Scopus and SciELO. The descriptor "imatinib" was used in two combinations employing the connector AND between terms: "medication adherence" AND "imatinib" AND "leukemia" and "patient compliance" AND "imatinib" AND "leukemia". We identified 476 studies, being 14 included in the study. The rates of adherence and discontinuation were diverse, ranging from 19.0 to $97.0 \%$ and from 1.8 and $41.0 \%$, respectively, and a high number of longitudinal studies was observed (71.4\%). Most studies used questionnaires as an indirect method to assess adherence and factors related to poor adherence were adverse drug reactions, dose changes and unavailability of the medication. Patient education associated with follow up by pharmacists and other health professionals can improve patient adherence and minimize the pharmacotherapy discontinuation.
\end{abstract}

Uniterms: Chronic Myeloid Leukemia/treatment. Imatinib Mesylate/treatment adherence. Medication adherence. Pharmacotheraphy review.

\section{INTRODUCTION}

Chronic myeloid leukemia (CML) represents 7 to $20 \%$ of all hematologic neoplasias, with an incidence between one and two cases per 100,000 individuals per year (Mauro et al., 2015). Its frequency is higher among adults aging between 55 to 60 years old and rare during childhood, accounting for only $3 \%$ of all the cases of CML (Tefferi et al., 2005; Suttorp, Millot, 2010). It affects both sexes, with a slight predominance in males in a ratio of 2.2 men for 1.4 women affected (Berger et al., 2005).

CML is characterized by a clonal myeloproliferative neoplasia of cells of the granulocyte lineage, which retains the abilities of maturation and differentiation (Perrotti

*Correspondence: L. R. Ayres. Departamento de Ciências Farmacêuticas. Centro de Ciências da Saúde. Universidade Federal do Espírito Santo (UFES). Avenida Marechal Campos, 1468 - 29043-900 - Maruípe,Vitória - ES, Brasil. Tel.: +55 (27) 3335-7556. E-mail:lorenaayres@hotmail.com et al., 2010). It is associated with a specific cytogenetic mutation on chromosome "Philadelphia" $(\mathrm{Ph})$ which is a cytogenetic marker of CML resulting from a reciprocal translocation between the long arms of chromosomes 9 and 22 containing the hybrid gene BCR/ABL. The coding of this gene is characterized by an enzyme with high tyrosine kinase activity responsible for the uncompensated cell proliferation, producing favorable conditions to the establishment of neoplastic process (Hehlmann, Hochhaus, Baccarani, 2007; Marin et al., 2010; Perrotti et al., 2010). Clinically, the stages of the disease are differentiated according to their evolution, being divided into chronic, accelerated and blast crisis or acute phases. In the acute phase, survival rates decrease drastically (Cortes, Kantarjian, 2012).

The therapeutic arsenal of CML comprises chemotherapeutic agents like busulfan and hydroxyurea, the immunobiological agent interferon $\alpha$, hematopoietic 
stem cells transplantation which is the only curative treatment and tyrosine kinase inhibitors represented by first generation drugs such as imatinib mesylate and second generation drugs such as nilotinib and dasatinib. Used since 2001, imatinib has become the first-line therapy in clinical protocol of CML due to some advantages such as low toxicity, oral administration and significant improvements in survival rates of patients undergoing treatment (85\%). Imatinib use during the chronic phase of the disease is able to provide complete hematologic response rates (CHR), complete cytogenetic remission (CCR) and complete molecular remission (CMR) higher than $90 \%$ (Cortes, Kantarjian, 2012; Chen et al., 2014; Anderson et al., 2015).

Adherence to treatment with tyrosine kinase inhibitors results in improved clinical outcomes and promotes reduction in health costs. However, some patients present poor adherence to tyrosine kinase inhibitors impairing the responses to the treatment (Noens et al., 2009; Hirji et al., 2013). Adherence to pharmacotherapy is the adequate compliance with the treatment regimen proposed by the doctor or other health care provider and is related to demographic and social conditions of the patient and to characteristics of the disease and the treatment (WHO, 2003). Intentional factors (lack of knowledge of the disease, travel, lack of efficacy) and unintentional (duration of treatment, adverse effects, unavailability in health services, forgetfulness, financial difficulties) can sometimes have an impact on patient adherence to treatment with imatinib mesylate, resulting in an increase in the mortality rate associated with the progression of CML (Noens et al., 2009; Eliasson et al., 2011).

One of the consequences related to non-adherence to imatinib is associated with resistance or intolerance to the drug. In this situation, many patients respond to tyrosine kinase inhibitors of second generation such as dasatinib and nilotinib, which are more potent drugs than imatinib and can improve the quality of life of patients with this clinical condition (Jabbour et al., 2012a; Bhamidipati et al., 2013). However, the survival rate of patients with CML adherent to imatinib is $16.9 \%$ higher compared to nonadherent patients. Non-adherence and/or discontinuation to imatinib reduces the possibility of CCR in $18 \%$ of CML cases (Ganesan et al., 2011). Thus, the adherence to imatinib can prevent complications or exacerbations of CML caused by treatment failures, which would result in hospitalizations and procedures related to increases in health care costs (Halpern et al., 2009; Cid et al., 2013).

Since adherence to imatinib is crucial for successful treatment of patients with CML, its evaluation is necessary. It can be performed by direct methods such as detection of drug or metabolite in biological fluids, addition of a biological marker and direct observation of the patient and/or indirect methods, which are simple and easy to perform such as patient diary, questionnaires, drug records, frequency of medication withdrawal in pharmacies, electronic monitoring of medication and manual pill count (Jabbour et al., 2012a; Pérez-Escamilla et al., 2015).

\section{Aim of the review}

This review was developed in order to evaluate and compare adherence and/or discontinuation rates to imatinib mesylate in patients with CML in different studies found in scientific literature.

\section{METHODS}

An integrative review was performed with original articles published in scientific literature from 2004 to 2014. This type of evaluation allows to incorporate studies with different methods, such as experimental and non-experimental studies, while the systematic review is primarily focused on experimental studies.

\section{Search Strategy}

The articles were searched in the PubMed/ MEDLINE, Scopus and SciELO databases. The Medical Subject Heading (MeSH) was used to define the descriptors. The descriptor "imatinib" was used in two combinations with the descriptors "medication adherence", "leukemia" and "patient compliance" using the connector AND between the terms: "medication adherence" AND "imatinib" AND "leukemia" and "patient compliance" AND "imatinib" AND "leukemia". The limits established to the search were publications between January $1^{\text {st }}, 2004$ and December $31^{\text {st }}, 2014$ and in English, Spanish and Portuguese languages.

\section{Inclusion and exclusion criteria}

In the first phase, the articles were identified using the search criteria and all the duplicate records were deleted.

In the second stage, a prior reading of the title and abstract of the selected articles was performed in order to include only original articles, which their main objective was to assess adherence rates and/or discontinuation of imatinib in patients with CML. Review articles, notes, correspondence, editorial and letter were excluded. In the last step, articles were excluded if they did not analyze 
the rates of adherence and/or discontinuation of imatinib. Original articles that addressed the issue of adherence were read in their entirety, in order to assess whether they should be included or not in the study.

\section{Data analysis}

Selected articles were subjected to a full analytical reading to identify the variables of interest: authorship, population size, age, disease stage, follow-up, study design, methods used to assess adherence and/or discontinuation, adherence and/or discontinuation rates and predictors related to poor adherence.

The collected data were gathered into a table for further analysis and interpretation. In case of any disagreement, a third researcher was consulted to establish a final agreement on the variable to be collected.

\section{RESULTS AND DISCUSSION}

We identified 476 articles through database search. Fourteen articles were included in the study according to the selection criteria (Figure 1).
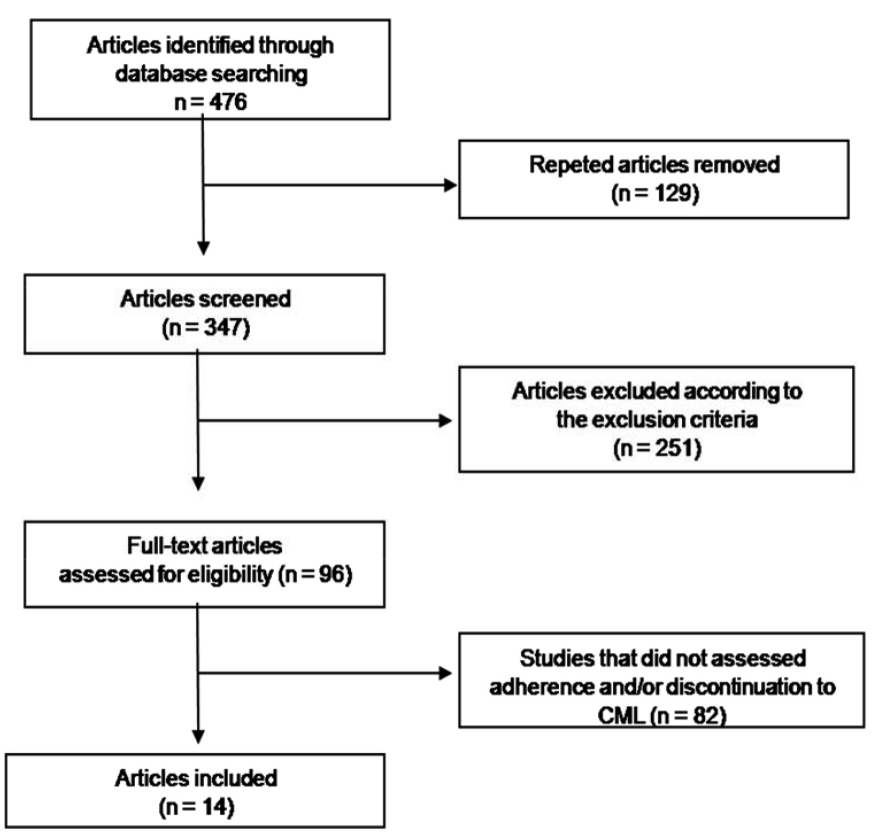

FIGURE 1 - Flowchart of the selected articles for the integrative review according to the criteria used in the study.

The studies in accordance with the inclusion criteria were published in English $(n=13)$ and Spanish $(n=1)$. The age range of the patients included in the evaluated studies ranged from 13 to 89 years. Chronic myeloid leukemia can occur in all age groups as observed in this study, but it is more common in adults and rare in childhood. However, no conclusive evidence suggests that age may be a factor involved in adherence to imatinib (Reis et al., 2013; Efficace et al., 2014). Some studies suggest higher adherence rates among younger patients (StCharles et al., 2009; Jabbour et al., 2012b), while others address that adherence is significantly lower among patients with advanced age, which often deal with chronic diseases, present decreased physical and cognitive activities and are more susceptible to complex treatment regimen due to the disease (Townsley et al.; 2005; Russo et al., 2013; Matikas et al., 2015). In relation to the stage of the disease, two studies included patients in blast crisis, four in accelerated phase and all studies evaluated the drug therapy in patients in the chronic phase of the disease (Table I).

The analyzed articles were conducted in developed or developing countries. However, even considering only studies performed in developed countries with similar socioeconomic characteristics, it was observed heterogeneity among the rates of adherence and discontinuation ranging from 19.0 to $97.0 \%$ and from $1.8 \%$ to $41.0 \%$, respectively. One reason for this heterogeneity may be related to the treatment period when the data collection was performed, since the patient adherence to the treatment at the beginning is higher (Reis et al., 2013). Evidences suggest that adherence to imatinib decreases throughout treatment period (Marin et al., 2010; Gater et al., 2012).

Among the selected studies, four were crosssectional, two were descriptive retrospective, four were longitudinal retrospective and four prospective studies. Regarding the longitudinal prospective, two were clinical study. Importantly, longitudinal studies provide answers related to the incidence of adherence and/or discontinuation of the drug prescribed during treatment (Ayres et al., 2014).

The indirect methods were used to evaluate adherence and/or discontinuation in the majority of the studies $(n=13)$, and questionnaire was the most employed instrument $(n=7)$. The analysis of medical records and Medication Possession Ratio (MPR) records was used in four studies and the evaluation of the hospital pharmacy database in one study. Both clinical studies have used imatinib plasma levels to assess adherence and/ or discontinuation. Furthermore, an association among different adherence methods was performed in four studies analyzed, Marin et al. (2010) used Medication Event Monitoring System (MEMS) combined with the drug detection in biological fluids, Noens et al. (2009) used structured questionnaire with manual tablets count, Eliasson et al. (2011) combined MEMS with questionnaire 
TABLE I - Analysis of published articles that evaluated the adherence and/or discontinuation of imatinib mesylate

\begin{tabular}{|c|c|c|c|c|c|c|c|c|}
\hline $\begin{array}{l}\text { Authors /year/ } \\
\text { Study Center } \\
\text { Coordinator } \\
\text { (Country) }\end{array}$ & $\begin{array}{c}\text { Number of } \\
\text { patients }\end{array}$ & Age / Age range & $\begin{array}{l}\text { Disease } \\
\text { Stage }\end{array}$ & $\begin{array}{c}\text { Follow-up } \\
\text { period (days, } \\
\text { months, years) }\end{array}$ & Study design & $\begin{array}{l}\text { Method of } \\
\text { adherence } \\
\text { evaluation }\end{array}$ & $\begin{array}{c}\text { Adherence } \\
\text { (A) and/or } \\
\text { Discontinuation } \\
\text { (D) }\end{array}$ & $\begin{array}{c}\text { Factors } \\
\text { associated to } \\
\text { poor adherence }\end{array}$ \\
\hline $\begin{array}{l}\text { Halpern et al. } \\
\text { (2009), USA }\end{array}$ & $\begin{array}{c}374 \text { (CML) } \\
465 \text { (in total) }\end{array}$ & $\begin{array}{c}\text { Mean } 50.8 \pm 14,1 \\
\text { years }\end{array}$ & $\mathrm{CP}$ & $\begin{array}{l}\text { Minimum of } 12 \\
\text { months }\end{array}$ & $\begin{array}{c}\text { Retrospective } \\
\text { Cohort }\end{array}$ & MPR & A: $70.1 \%$ & ------- \\
\hline
\end{tabular}

\begin{tabular}{|c|c|c|c|c|c|c|c|c|}
\hline $\begin{array}{l}\text { Noens et al. } \\
\text { (2009), Spain }\end{array}$ & 169 & $17-86$ years & $\mathrm{AP} / \mathrm{CP}$ & 90 days & $\begin{array}{c}\text { Prospective } \\
\text { Observational }\end{array}$ & $\begin{array}{c}\text { Structured } \\
\text { questionnaire/ } \\
\text { Manual tablet } \\
\text { count }\end{array}$ & $\begin{array}{l}\text { A: } 67.3 \% \\
\text { D: } 1.8 \%\end{array}$ & $\begin{array}{l}\mathrm{H} \text { igh e r a ge, } \\
\text { male sex, longer } \\
\text { time since CML } \\
\text { diagnosis, living } \\
\text { alone, imatinib } \\
\text { dose } \geq 600 \mathrm{mg} / \\
\text { day }\end{array}$ \\
\hline $\begin{array}{l}\text { Eliasson et al. } \\
\text { (2011), UK }\end{array}$ & 21 & $26-70$ years & $\mathrm{CP}$ & ------ & Cross-sectional & $\begin{array}{c}\text { MEMS/ } \\
\text { Questionnaire }\end{array}$ & A: $19 \%$ & $\begin{array}{l}\text { Forgetting, no } \\
\text { imatinib available } \\
\text { at pharmacy, } \\
\text { ADR, travelling, } \\
\text { s o c i a l is ing / } \\
\text { drinking alcohol }\end{array}$ \\
\hline $\begin{array}{l}\text { Efficace } \text { et al. } \\
\text { (2012), USA }\end{array}$ & 413 & $20-87$ years & $\mathrm{CP}$ & ------ & Cross-sectional & $\begin{array}{c}\text { Structured } \\
\text { questionnaire }\end{array}$ & A: $53 \%$ & $\begin{array}{l}\text { Mental health } \\
\text { dysfunction, } \\
\text { lower level of } \\
\text { social support }\end{array}$ \\
\hline $\begin{array}{l}\text { Jönsson et al. } \\
\text { (2012), Sweden }\end{array}$ & 38 & $26-88$ years & $\mathrm{CP}$ & 12 months & $\begin{array}{c}\text { Prospective } \\
\text { Cohort }\end{array}$ & $\begin{array}{c}\text { Structured } \\
\text { Questionnaire }\end{array}$ & A: $97 \%$ & $\begin{array}{l}\text { Lower leve } 1 \\
\text { of information, } \\
\text { difficult access to } \\
\text { the treating clinic }\end{array}$ \\
\hline $\begin{array}{l}\text { Cid et al. (2013), } \\
\text { Brazil }\end{array}$ & 100 & $21-40$ years & $\mathrm{AP} / \mathrm{BP} / \mathrm{CP}$ & ------ & $\begin{array}{c}\text { Retrospective } \\
\text { Descriptive }\end{array}$ & MPR & $\begin{array}{l}\text { A: } 53 \% \\
\text { D: } 17 \%\end{array}$ & $\mathrm{ADR} /$ Intolerance \\
\hline $\begin{array}{l}\text { Santoleri et al. } \\
\text { (2013), Italy }\end{array}$ & 63 & $14-88$ years & $\mathrm{CP}$ & 39 months & $\begin{array}{l}\text { Retrospective } \\
\text { Observational }\end{array}$ & $\begin{array}{c}\text { Hospital } \\
\text { pharmacy } \\
\text { database }\end{array}$ & $\begin{array}{l}\text { A: } 83 \% \\
\text { D: } 10 \%\end{array}$ & $\begin{array}{l}\text { Significant ADR, } \\
\text { poor patient } \\
\text { involvement in } \\
\text { treatment }\end{array}$ \\
\hline $\begin{array}{l}\text { Chen et al. } \\
\text { (2014), Taiwan }\end{array}$ & 119 & $\begin{array}{c}\text { Mean } 45.7 \pm 16.9 \\
\text { years }\end{array}$ & $\mathrm{CP}$ & $\begin{array}{c}\text { Mean } 3.9 \pm 2.9 \\
\text { years }\end{array}$ & $\begin{array}{c}\text { Retrospective } \\
\text { Cohort }\end{array}$ & $\begin{array}{c}\text { MPR/Biological } \\
\text { marker }\end{array}$ & $\begin{array}{l}\text { A: } 73.1 \% \\
\text { D: } 38.6 \%\end{array}$ & $\begin{array}{l}\text { ADR, lower level } \\
\text { of social and } \\
\text { medical support, } \\
\text { accessibility } \\
\text { p o b l e m s, } \\
\text { ineffectiveness }\end{array}$ \\
\hline
\end{tabular}


TABLE I - Analysis of published articles that evaluated the adherence and/or discontinuation of imatinib mesylate (cont.)

\begin{tabular}{|c|c|c|c|c|c|c|c|c|}
\hline $\begin{array}{l}\text { Authors /year/ } \\
\text { Study Center } \\
\text { Coordinator } \\
\text { (Country) }\end{array}$ & $\begin{array}{c}\text { Number of } \\
\text { patients }\end{array}$ & Age / Age range & $\begin{array}{c}\text { Disease } \\
\text { Stage }\end{array}$ & $\begin{array}{c}\text { Follow-up } \\
\text { period (days, } \\
\text { months, years) }\end{array}$ & Study design & $\begin{array}{l}\text { Method of } \\
\text { adherence } \\
\text { evaluation }\end{array}$ & $\begin{array}{c}\text { Adherence } \\
\text { (A) and/or } \\
\text { Discontinuation } \\
\text { (D) }\end{array}$ & $\begin{array}{c}\text { Factors } \\
\text { associated to } \\
\text { poor adherence }\end{array}$ \\
\hline $\begin{array}{l}\text { Efficace et al. } \\
\text { (2014), Italy }\end{array}$ & 175 & $20-87$ years & $\mathrm{CP}$ & ------- & Cross-sectional & $\begin{array}{c}\text { Structured } \\
\text { Questionnaire }\end{array}$ & A: Not assessed* & $\begin{array}{l}\text { ADR, older age, } \\
\text { male sex }\end{array}$ \\
\hline $\begin{array}{l}\text { Gotta et al. } \\
\text { (2014), Italy }\end{array}$ & 56 & $44-73$ years & $\mathrm{AP} / \mathrm{CP}$ & 13 months & Clinical study & $\begin{array}{c}\text { Drug detection in } \\
\text { biological fluids }\end{array}$ & D: $23 \%$ & $\begin{array}{l}\text { ADR/Intolerance, } \\
\text { failure* }\end{array}$ \\
\hline
\end{tabular}

MPR - Medication Possession Ratio; ADR - Adverse Drug Reaction; MEMS - Microelectronic Monitoring System; CP - Chronic Phase; AP - Accelerated Phase; BP - Blastic Phase. *In this study, only suboptimal adherers were included and classified based on their stated reasons for not adhering exactly as prescribed by their physicians.

e and Chen et al. (2014) combined MPR with a biological marker detection.

Considering the methods to evaluate adherence, it was evidenced that the adherence rates was lower in studies that used questionnaires as data collection source compared to other assessment methods (Noens et al., 2009; Efficace et al., 2012; Hirji et al., 2013; Rosa et al., 2013). Although the questionnaire allows the follow-up of a large number of individuals and it is a low-cost and fast strategy, it is a method subject to bias and may interfere with the measurement of adherence, overestimating or underestimating the current medication adherence rate (Bloch, Melo, Nogueira, 2008; Ben, Neumann, Mengue, 2012; Pérez-Escamilla et al., 2015).

Additionally a high adherence rate was found in studies that used the association between direct and indirect methods (Marin et al., 2010; Chen et al., 2014). It is important to mention that MEMS is a very costly method and subject to sampling errors. Despite these disadvantages, it allows to estimate the frequency of daily intake and interval between doses. On the other hand, drug detection in biological fluids, although it is a method of high financial cost, which evaluates only the recent drug use, it can eliminate the interference of patient's report in assessing adherence (Pérez-Escamilla et al., 2015). The differences found in adherence and/or discontinuation rates may be justified by the use of different instruments to estimate the incidence and/or prevalence of patient adherence and/or discontinuation (Wetzels et al., 2006).

Evidence shows that there is no ideal method for evaluating medication adherence. Each assessment tool has advantages and disadvantages that favor or limit their applicability (Pérez-Escamilla et al., 2015). A systematic review of over 6500 citations, with full review of 549 articles published between 1967 and 2001, showed there is no effective approach to assess adherence and that most of the methods used to evaluate adherence in a context of chronic diseases are generally complicated, expensive, and not consistently successful (Jabbour et al., 2012a). Thus, the authors suggest the combination of methods to monitor medication adherence with the purpose of reducing biases and inherent limitations to each instrument.

Regardind the rates of adherence and discontinuation among patients with CML in all studies included in this review, there was a variation of 19.0 to $97.0 \%$ and 1.8 to $41.0 \%$, respectively. Among the 14 studies analyzed, seven referred only to adherence, one referred only to discontinuation, five assess adherence and discontinuation and one included only suboptimal adherers. It was evident that few studies have assessed the achievement of cytogenetic and molecular response, which are important parameters for analyzing the absence of Philadelphia chromosome, as well as reduced levels of BCL-ABL rearrangement (Marin et al., 2010; Cid et al., 2013; Reis et al., 2013). In addition, four studies showed adherence rates relatively low to imatinib, such as between 19.0 and $53.0 \%$. It has been shown in clinical trials that reduced adherence rates are associated with lower rates of CCR and CMR (Marin et al., 2010; Cid et al., 2013). In the clinical context, several factors may influence adherence to treatment regimens and these include not only those aspects of the treatment, but also patient characteristics (Partridge et al., 2002; Efficace et al., 2012).

Factors related to poor adherence such as adverse drug reactions (ADRs) and unavailability of drugs were seen as major causes for discontinuation and/or nonadherence to imatinib. Nine studies analyzed showed that adverse reactions to imatinib were related to non-adherence and/or intentional discontinuation. Drug unavailability was a factor related to discontinuation and/or non-adherence in three studies. Low social support, advanced age, poor access to health care, low level of information, prolonged treatment and high daily doses are other examples of factors associated to discontinuation and/or non-adherence. 
The ADRs are expected and explained by the the mechanism of action of the drug and can be correlated with changes in the drug dosage (Eliasson et al., 2011; Efficace et al., 2012; Rosa et al., 2013; Chen et al., 2014; Gotta et al., 2014). This was evidenced in two studies included in this work that showed that patients who took an increased dosage of imatinib had significantly lower adherence than patients who remained taking lower doses (Noens et al., 2009; Marin et al., 2010). These dosage changes may affect therapeutic results, since rising the dose can increase the incidence of ADR, thereby lowering the adherence to the treatment over time (Chen et al., 2014).

Studies conducted in the USA show that nonadherence to treatment may be associated with high healthcare costs, since it decreases the effectiveness of the treatment and requires a prolonged treatment period culminating in increased costs to the healthcare system (Reinhardt, Hussey, Anderson, 2004; Halpern et al., 2009). Another important aspect related to the non-adherence and/or discontinuation to be considered is relative to the availability of medicines in developing countries. The unstructured healthcare systems and failures in pharmaceutical care policies of the developing countries impair the access to medicines and can contribute to non-intentional discontinuation of the treatment by the patients. Studies performed in Brazil showed that less than half of people who have prescription drugs in the public healthcare system have access to all of them (Boing et al., 2013) and the most frequent reason for non-adherence is the unavailability of the drug at the healthcare system (Reis et al., 2013). Moreover, studies show that the lack of access to medicines can generate not only a direct impact on clinical, social and economic conditions of the patient, but also an increase in spending on secondary and tertiary care (Reis, Perini, 2008).

Knowing the current rates of adherence and/ or discontinuation is essential to develop strategies to improve pharmacotherapeutic results. Thus, it is worth noting that the follow-up of patients that take oral medication for CML plays a key role in promoting and improving adherence to treatment and also to identify, prevent and solve other drug related problems. Welltrained pharmacists can solve those problems through interventions such as medication management, providing information and guidance that improve adherence to drug therapy and that increase the effectiveness and medication safety (Partridge et al., 2002; Weingart et al., 2008).

\section{CONCLUSION}

In this study, we observed diverse rates of adherence and/or discontinuation of imatinib, ranging from 19.0 to $97.0 \%$ and from 1.8 and $41.0 \%$, respectively. This can be due to the use of various tools to access adherence, different treatment period when data collection of the studies was conducted and by socioeconomic differences among countries, health systems, age range and changes in dosage. Few studies evaluated cytogenetic and molecular responses to imatinib treatment being necessary further efforts of the clinical research community in this aspect. Besides that, there is a lack of studies of the predictors for adherence and/or discontinuation of imatinib. Therefore, health professionals should also be able to identify predictors of poor adherence to imatinib, which allows them to seek for strategies that improves adherence and consequently leads to better clinical outcomes. Therefore, this study showed that patient education combined with a follow-up by pharmacists or other health professionals can maximize patient adherence and minimize discontinuation of pharmacotherapy.

\section{ACKNOWLEDGEMENTS}

The authors would like to thank the University of São João Del Rei for its support during the research.

\section{REFERENCES}

ANDERSON, K.R.; CHAMBERS, C.R.; LAM, N.; YAU, P.S.; CUSANO, F.; SAVOIE, M.L.; SHEIKH, N. Medication adherence among adults prescribed imatinib, dasatinib, or nilotinib for the treatment of chronic myeloid leukemia. $J$. Oncol. Pharm. Pract., v.21, n.1, p.19-25, 2015.

AYRES, L.R.; BALDONI, A.O.; BORGES, A.P.; PEREIRA, L.R. Adherence and discontinuation of oral hormonal therapy in patients with hormone receptor positive breast cancer. Int. J. Clin. Pharm., v.36, n.1, p.45-54, 2014.

BEN, A.J.; NEUMANN, C.R.; MENGUE, S.S. Teste de Morisky Green e Brief Medication Questionnaire para avaliar adesão a medicamentos. Rev.. Saúde Públ., v.46, n.2, p.279-89, 2012.

BERGER, U.; MAYWALD, O.; PFIRRMANN, M.; LAHAYE, T.; HOCHHAUS, A.; REITER, A.; HASFORD, J.; HEIMPEL, H.; HOSSFELD, D.K.; KOLB, H.J.; LÖFFLER, H.; PRALLE, H.; QUEISSER, W.; HEHLMANN, R. Gender aspects in chronic myeloid leukemia: long-term results from randomized studies. Leukemia, v.19, n.6, p.984-9, 2005. 
BHAMIDIPATI, P.K.; KANTARJIAN, H.; CORTES, J.; CORNELISON, A.M.; JABBOUR, E. Management of imatinib-resistant patients with chronic myeloid leukemia. Ther. Adv. Hematol., v.4, n.2, p.103-17, 2013.

BLOCH, K.V.; MELO, N.A.; NOGUEIRA, A.R. Prevalência da adesão ao tratamento anti-hipertensivo em hipertensos resistentes e validação de três métodos indiretos de avaliação da adesão. Cad. Saúde Públ., v.24, n.12, p.297984, 2008.

BOING, A.C.; BERTOLDI, A.D.; BOING, A.F.; BASTOS, J.L.; PERES, K. G. Access to medicines in the public sector: analysis of users of the Brazilian Unified National Health System. Cad. Saúde Públ., v.29, p.691-701, 2013.

CHEN, T.C.; CHEN, L.C.; HUANG, Y.B.; CHANG, C.S. Imatinib adherence associated clinical outcomes of chronic myeloid leukaemia treatment in Taiwan. Int. J. Clin. Pharm., v.36, n.1, p.172-81, 2014.

CID, D.M; MAGALHÃES, S.M.; QUIXADÁ, A.T.; HONÓRIO, R.P.; COSTA, P.F.; REIS, S.R.; CARVALHO, S.M.; CID, D.A.; SUCUPIRA, R.M.; DE OLIVEIRA, M.F. Chronic myeloid leukemia: an overview of the determinants of effectiveness and therapeutic response in the first decade of treatment with imatinib mesylate in a Brazilian hospital. Rev.Bras. Hematol. Hemoter., v.35, n.6, p.389-94, 2013.

CORTES, J.; KANTARJIAN, H. How I treat newly diagnosed chronic phase CML. Blood, v.120, n.7, p.1390-7, 2012.

EFFICACE, F.; BACCARANI, M.; ROSTI, G.; COTTONE, F.; CASTAGNETTI, F.; BRECCIA, M.; ALIMENA, G.; IURLO, A.; ROSSI, A.R.; PARDINI, S.; GHERLINZONI, F.; SALVUCCI, M.; TIRIBELLI, M.; VIGNETTI, M.; MANDELLI, F. Investigating factors associated with adherence behaviour in patients with chronic myeloid leukemia: an observational patient-centered outcome study. Br. J. Cancer, v.107, n.6, p.904-9, 2012.

EFFICACE, F.; ROSTI, G.; COTTONE, F.; BRECCIA, M.; CASTAGNETTI, F.; IURLO, A.; MANDELLI, F.; BACCARANI, M. Profiling chronic myeloid leukemia patients reporting intentional and unintentional nonadherence to lifelong therapy with tyrosine kinase inhibitors. Leuk. Res., v.38, n.3, p.294-8, 2014.
ELIASSON, L.; CLIFFORD, S.; BARBER, N.; MARIN, D. Exploring chronic myeloid leukemia patients' reasons for not adhering to the oral anticancer drug imatinib as prescribed. Leuk. Res., v.35, n.5, p.626-30, 2011.

GANESAN, P.; SAGAR, T.G.; DUBASHI, B .; RAJENDRANATH, R.; KANNAN, K.; CYRIAC, S.; NANDENNAVAR, M. Nonadherence to imatinib adversely affects event free survival in chronic phase chronic myeloid leukemia. Am. J. Hematol., v.86, n.6, p. 471-4, 2011.

GATER, A.; HERON, L; ABETZ-WEBB, L.; COOMBS, J.; SIMMONS, J.; GUILHOT, F.; REA, D. Adherence to oral tyrosine kinase inhibitor therapies in chronic myeloid leukemia. Leuk. Res., v.36, n.7, p.817-25, 2012.

GOTTA, V.; WIDMER, N.; DECOSTERD, L.A.; CHALANDON, Y.; HEIM, D.; GREGOR, M.; BENZ, R.; LEONCINI-FRANSCINI, L.; BAERLOCHER, G.M.; DUCHOSAL, M.A.; CSAJKA, C.; BUCLIN, T. Clinical usefulness of therapeutic concentration monitoring for imatinib dosage individualization: results from a randomized controlled trial. Cancer Chemother. Pharmacol., v.74, n.6, p.1307-19, 2014.

HALPERN, R.; BARGHOUT, V.; ZAROTSKY, V.; WILLIAMS, D.E. Costs and utilization associated with imatinib adherence in patients with chronic myeloid leukemia or gastrointestinal stromal tumors. JCOM, v.16, n.5, p.215-23, 2009.

HEHLMANN, R.; HOCHHAUS, A.; BACCARANI, M. Chronic myeloid leukemia. Lancet, v.370, n.9584, p.342$50,2007$.

HIRJI, I.; GUPTA, S.; GOREN, A.; CHIROVSKY, D.R.; MOADEL, A.B.; OLAVARRIA, E.; VICTOR, T.W.; DAVIS, C.C. Chronic myeloid leukemia (CML): association of treatment satisfaction, negative medication experience and treatment restrictions with health outcomes, from the patient's perspective. Health Qual. Life Outcomes, v.11, p.167, 2013. DOI: 10.1186/1477-7525-11-167.

JABBOUR, E.J.; KANTARJIAN, H.; ELIASSON, L.; CORNELISON, A.M.; MARIN, D. Patient adherence to tyrosine kinase inhibitor therapy in chronic myeloid leukemia. Am. J. Hematol., v.87, n.7, p.687-91, 2012a.

JABBOUR, E.; SAGLIO, G.; RADICH, J.; KANTARJIAN, H. Adherence to BCR-ABL inhibitors: issues for CML therapy. Clin. Lymphoma Myeloma Leuk., v.12, n.4, p.223-9, 2012 b. 
JÖNSSON, S.; OLSSON, B.; SÖDERBERG, J.; WADENVIK, $\mathrm{H}$. Good adherence to imatinib therapy among patients with chronic myeloid leukemia--a single-center observational study. Ann. Hematol., v.91, n.5, p.679-85, 2012.

MARIN, D.; BAZEOS, A.; MAHON, F.X.; ELIASSON, L.; MILOJKOVIC, D.; BUA, M.; APPERLEY, J.F.; SZYDLO, R.; DESAI, R.; KOZLOWSKI, K.; PALIOMPEIS, C.; LATHAM, V.; FORONI, L.; MOLIMARD, M.; REID, A.; REZVANI, K.; DE LAVALLADE, H.; GUALLAR, C.; GOLDMAN, J.; KHORASHAD, J.S. Adherence is the critical factor for achieving molecular responses in patients with chronic myeloid leukemia who achieve complete cytogenetic responses on imatinib. J. Clin. Oncol., v.28, n.14, p.2381-8, 2010.

MATIKAS, A.; ASIMAKOPOULOU, N.; GEORGOULIAS, V.; SOUGLAKOS, J. The place of targeted agents in the treatment of elderly patients with metastatic colorectal cancer. Cancers, v.7, p.439-49, 2015.

MAURO, M.J.; DAVIS, C.; ZYCZYNSKI, T.; KHOURY, H.J. The role of observational studies in optimizing the clinical management of chronic myeloid leukemia. Ther. Adv. Hematol., v.6, n.1, p.3-14, 2015.

NOENS, L.; VAN LIERDE, M.A.; DE BOCK, R.; VERHOEF, G.; ZACHÉE, P.; BERNEMAN, Z.; MARTIAT, P.; MINEUR, P.; VAN EYGEN, K.; MACDONALD, K.; DE GEEST, S.; ALBRECHT, T.; ABRAHAM, I. Prevalence, determinants, and outcomes of nonadherence to imatinib therapy in patients with chronic myeloid leukemia: the ADAGIO study. Blood, v.113, n.22, p.5401-11, 2009.

PARTRIDGE, A.H.; AVORN, J.; WANG, P.S.; WINER, E.P. Adherence to therapy with oral antineoplastic agents. $J$. Natl. Cancer Inst., v.94, n.9, p.652-61, 2002.

PÉREZ-ESCAMILLA, B.; FRANCO-TRIGO, L.; MOULLIN, J.C.; MARTÍNEZ-MARTÍNEZ, F.; GARCÍA-CORPAS, J.P. Identification of validated questionnaires to measure adherence to pharmacological antihypertensive treatments. Patient Prefer. Adherence, v.9, p.569-78, 2015.

PERROTTI, D.; JAMIESON, C.; GOLDMAN, J.; SKORSKI, T. Chronic myeloid leukemia: mechanisms of blastic transformation. J. Clin. Invest., v.120, n.7, p.2254-64, 2010.

REINHARDT, U.E.; HUSSEY, P.S.; ANDERSON, G.F. U.S. health care spending in an international context. Health Aff., v.23, n.3, p.10-25, 2004.
REIS, A.M.M.; PERINI, E. Desabastecimento de medicamentos: determinantes, conseqüências e gerenciamento. Ciênc. Saúde Colet., v.13, p.608-10, 2008.

REIS, S.R.; QUIXADÁ, A.T.; NUNES, S.T.; CID, D.M.; DE SOUZA, J.H.; DA COSTA, C.M.; SILVEIRA, C.B.; CID, D.A.; DE OLIVEIRA, M.F. Adherence to treatment with imatinib in chronic myeloid leukemia: a study of the first decade of responses obtained at a Brazilian hospital. Rev. Bras. Hematol. Hemoter, v.35, n.3, p.174-9, 2013.

ROSA, V.G.; NICOLAS, F.G.; MORENO RG, ROMERO MV, CARVAJAL TM, PÉREZ RG. Adherencia y toxicidad de los inhibidores de la tirosinquinasa en leucemia mieloide crônica. Farm. Hosp., v.37, n.6, p.434-40, 2013.

RUSSO, D.; MALAGOLA, M.; SKERT, C.; FILÌ, C.; BERGONZI, C.; CANCELLI, V.; CATTINA, F. Treatment of chronic myeloid leukemia elderly patients in the tyrosine kinase inhibitor era. Curr. Cancer Drug Targets, v.13, n.7, p.755-67, 2013.

SANTOLERI, F.; SORICE, P.; LASALA, R.; RIZZO, R.C.; COSTANTINI, A. Patient adherence and persistence with imatinib, nilotinib, dasatinib in clinical practice. PLoS One. v.8, n.2, 2013. DOI:10.1371/journal.pone.0056813.

ST CHARLES, M.; BOLLU, V.K.; HORNYAK, E.; COOMBS, J.; BLANCHETTE, C.M.; DEANGELO, D.J. Predictors of treatment non-adherence in patients treated with imatinib mesylate of chronic myeloid leukemia. In: AMERICAN SOCIETY OF HEMATOLOGY ANNUAL MEETING AND EXPOSITION, 51, 2009, New Orleans. Blood, 2009. Abstracts Washington: ASH, 2009. Abstract no. 2209.

SUTTORP, M.; MILLOT, F. Treatment of pediatric chronic myeloid leukemia in the year 2010: Use of tyrosine kinase inhibitors and stem-cell transplantation. Hematol. Am. Soc. Hematol. Educ. Progr., v.2010, n.1, p.368-76, 2010.

TEFFERI, A.; DEWALD, G.W.; LITZOW, M.L.; CORTES, J.; MAURO, M.J.; TALPAZ, M., KANTARJIAN, H.M. Chronic myeloid leukemia: current application of cytogenetics and molecular testing for diagnosis and treatment. Mayo Clin. Proc., v.80, n.3, p.390-402, 2005.

TOWNSLEY, C.; POND, G.R.; PELOZA, B.; KOK, J.; NAIDOO, K.; DALE, D.; HERBERT, C.; HOLOWATY, E.; STRAUS, S.; SIU, L.L. Analysis of treatment practices for elderly cancer patients in Ontario, Canada. J. Clin. Oncol., v.23, n.16, p.3802-10, 2005. 
WEINGART, S.N.; BROWN, E.; BACH, P.B.; ENG, K.; JOHNSON, S.A.; KUZEL, T.M.; LANGBAUM, T.S.; LEEDY, R.D.; MULLER, R.J.; NEWCOMER, L.N.; O'BRIEN, S.; REINKE, D.; RUBINO, M.; SALTZ, L.; WALTERS, R.S. NCCN task force report: oral chemotherapy. J. Natl. Compr. Canc. Netw., v.6, Suppl.3, p.S1-14, 2008.

WETZELS, G.E.; NELEMANS, P.J.; SCHOUTEN, J.S.; VAN WIJK, B.L.; PRINS, M.H. All that glisters is not gold: a comparison of electronic monitoring versus filled prescriptions-an observational study. BMC Health Serv. Res., v.6, p.8, 2006. DOI:10.1186/1472-6963-6-8.
WORLD HEALTH ORGANIZATION. WHO. Adherence to long-term therapies. Evidence for action. Geneva: WHO, 2003. 194p.

Received for publication on $20^{\text {th }}$ January 2016 Accepted for publication on $05^{\text {th }}$ October 2016 
